\title{
PENGEMBANGAN MODEL MANAJEMEN MUTU PENDIDIKAN PADA SMK DI KOTA BANDUNG
}

\author{
Endang Herawan, Dedy Achmad Kurniady, Sururi \\ email: endang_herawan@gmail.com \\ Dosen Universitas Pendidikan Indonesia
}

\begin{abstract}
ABSTRAK
Penelitian ini dilakukan atas dasar adanya hasil pengamatan ada beberapa lulusan SMK sudah mampu bersaing dengan lulusan pendidikan tinggi, tetapi hal tersebut masih sebagian kecilnya saja dan itupun bagi lulusan yang memang mempunyai daya juang dan kreativitas yang tinggi. Walaupun inovasi-inovasi pembelajaran yang dilakukan sekolah dan daya dukung dari pihak dunia usaha dan industry disinyalir terjadi peningkatan, namun tetap saja menimbulkan permasalahan yang sepertinya mengulang masalah lalu. Model Pengembangan Manajemen Mutu Pendidikan kaitannya dengan efektivitas penyelenggaraan pendidikan SMK di Kota Bandung bertujuan untuk: 1) Memverifikasi dan mendeskripsikan data tentang rencana dan program pendidikan yang dikembangkan dalam upaya meningkatkan mutu dan relevansi pendidikan, 2) Memverifikasi, mendeskripsikan dan memaknai strategi pelaksanaan rencana dan program pendidikan pada SMKN di Kota Bandung, 3) Memverifikasi dan mendeskripsikan pengawasan yang dilaksanakan oleh pimpinan sekolah, dan 4) Memverifikasi upaya-upaya perbaikan guna mewujudkan pendidikan yang bermutu dan relevan dengan kebutuhan dunia industri. Hasil penelitian sementara ini menemukan bahwa secara prinsipnya sekolah sudah mempunyai model manajemen mutu, dengan mengembangkan system penjaminan mutu berbasis pada ISO 9001:2008. Namun, system tersebut baru hanya sebatas pada prosedur dan prasyarat untuk kepentingan akteditasi dan menarik perhatian bagi pengguna jasa pendidikan, belum sepenuhnya menjadi landasan atau dasar dalam menjalankan proses pendidikan yang dapat menghasilkan lulusan sesuai dengan kebutuhan dunia usaha dan industry. Berdasarkan hal tersebut, maka sudah sewajarnya penelitian yang berkaitan dengan pengembangan model manajemen mutu pendidikan di SMK perlu dilakukan, sebagai bahan pertimbangan dan rujukan dalam rangka lebih meningkatkan hasil pendidikan yang bermutu.
\end{abstract}

Kata Kunci: manajemen mutu, perencanaan mutu, pengendalian/pengendalaian mutu, dan penjaminan mutu

\section{ABSTRACT}

This research was conducted on the basis of the information from the observation that is obtain that there are some vocational graduates have been able to compete with graduates of higher education or university, but it is still only a small part and it is also for graduates who really have the fighting spirit and high creativity. Although many innovations study was conducted by the school and carrying or supporting capacity from business and industry pointed out an increase, but it is still raises some problems that seem to repeat the problem faced before. The management development model of education quality regarding to the effectiveness of the implementation of vocational education in Bandung city aims to: 1) verify and describe the data about plans and educational programs that is developed in an effort to improve the quality and relevance of education, 2) Verify, describe and interpret the implementation plan strategy and educational programs at SMK in Bandung, 3) Verify and describe the administrative that is conducted by school leaders, and 4) Verify the remediation efforts to achieve quality education and also relevant to industry needs. The results of this study recently found principally, the school already has a model of quality management by developing a quality assurance system based on ISO 9001: 2008. However, the system was only limited to the procedures and prerequisites for accreditation and attract an interest for users of educational services, it had not fully become basis in running the educational process that can produce graduates according to the needs of business and industry. Based on the point, it is logically that research is related to the development model of quality management of education in vocational education needs to be done, and as a consideration and referral in order to further improve the quality of educational outcomes.

Keywords: quality management, quality planning, control / restraint quality, and pledgin quality 


\section{PENDAHULUAN}

Pengembangan sumber daya manusia di Indonesia masih dirasakan kurang mengarah kepada kondisi yang diharapkan. Hal ini dapat dilihat dari penguasaan kompetensi dan produktivitas tenaga kerja yang dihasilkan masih rendah dibandingkan tenaga kerja negara lainnya di kawasan Asia Tenggara, sehingga tenaga kerja Indonesia sulit bersaing, bahkan tidak sedikit peluang pekerjaan yang ada di Indonesia sendiri diisi oleh pekerja asing.

Berdasarkan hasil pengamatan, walaupun ada beberapa lulusan SMK sudah mampu bersaing dengan lulusan pendidikan tinggi, tetapi hal tersebut masih sebagian kecilnya saja dan itupun bagi lulusan yang memang mempunyai daya juang dan kreativitas yang tinggi.

Meskipun kualitas pendidikan kejuruan dirasakan masih kurang memuaskan, tetapi SMK merupakan salah satu sekolah yang diyakini mampu menciptakan produk pendidikan yang inovatif, kreatif, dan produktif. (Supriadi 2002:17-18):" Hal ini karena pendidikan kejuruan bertujuan untuk menghasilkan manusia yang produktif, yakni manusia kerja, bukan manusia beban bagi keluarga, masyarakat, dan bangsanya. Karena itu jenjang sekolah kejuruan merupakan salah satu alternatif terbaik dalam rangka meningkatkan mutu manusia Indonesia secara keseluruhan.

Pendidikan yang berkualitas ditandai oleh lulusan yang memiliki kompetensi dan mampu bersaing dalam dunia usaha yang lahir dari implementasi manajemen mutu pendidikan yang baik.menjawab tantangan permasalahan ketenagakerjaan diperlukan lembaga pendidikan kejuruan yang handal dan mampu menerapkan TQM.Kemampuan SMK untuk melaksanakan manajemen mutu, pada saat ini merupakan suatu tuntutan, sehingga lulusan yang dihasilkan oleh lembaga ini mampu mengatasi masalah pengangguran dan ketenagakerjaan yang hingga saat ini masih dikeluhkan oleh dunia usaha/dunia industri.

Adapun fokus dalam penelitian ini adalah mengenai pelaksanaan manajemen mutu pada SMK kelompok Bisnis Manajemen, yaitu SMK Negeri 1, SMK Negeri 3, dan SMK Pasundan 1. Sekolah menengah kejuruan sebagai lembaga pendidikan yang berfungsi untuk menyiapkan siswa untuk bekerja atau wirausaha dan mengikuti pendidikan lebih lanjut, hendaknya mampu memberikan layanan pendidikan yang bermutu, yakni yang dapat memenuhi harapan dan kebutuhan pelanggan eksternal, yaitu dunia usaha/ industri maupun internal yaitu siswa.

Layanan yang bermutu yang diberikan oleh pihak sekolah dapat dilihat dari aspek pendidikan sebagai suatu sisten, yaitu 1). Input, yang meliputi: visi, misi, tujuan sekolah, kebijakan, kurikulum atau program pembelajaran, fasilitas belajar, rumusan standar kompetensi, tenaga kependidikan yang profesional. 2). Proses atau strategi pembelajaran yang dikembangkan oleh pihak sekolah atau guru, yang meliputi penggunaan strategi pembelajaran dan evaluasi serta partisitipasi dunia usaha dalam perencanaan, pelaksanaan PBM dan evaluasi pembelajaran,3) sistem pengawasan dan pengendalian, yang mencakup penetapan ruang lingkup pengawasan, strategi pengawasan, tindak lanjut pengawasan berupa upaya peningkatan dan perbaikan pada rumusan kompetensi siswa, kurikulum, pelaksanaan proses pembelajaran dan sistem evaluasi pembelajaran sehingga relevan dengan kebutuhan dunia kerja maupun masyarakat.

Rumusanmasalahpenelitianiniakandiuraikan dalam beberapa pertanyaan penelitian berikut ini: (1) Bagaimanakah perencanaan mutu yang dilakukan oleh pimpinan SMK di Kota Bandung ?; (a) Pedoman mutu apa yang menjadi dasar dalam menyiapkan lulusan 
yang memiliki kemampuan untuk bekerja, melanjutkan pendidikan dan wirausaha?; (b) Kebijakan mutu apakah yang ditetapkan oleh pimpinan SMK di Kota Bandung dalam menyiapkan lulusan yang memiliki kemampuan untuk bekerja, melanjutkan pendidikan dan wirausaha?; dan (c) Rumusan standar kompetensi siswa apasajakah yang ditetap-kan oleh SMK di Kota Bandung?; (2) Bagaimanakah pelaksanaan manajemen mutu yang dilakukan oleh SMK di Kota Bandung dalam menyiapkan lulusan agar memiliki kemampuan untuk bekerja, melanjutkan pendidikan dan wirausaha?; (a) Kurikulum apa yang dikembangkan ?; dan (b) Bagaimana strategi implementasi kurikulum yang dilaksanakan?; (3) Bagaimanakah system pengendalian dan pengawasan manajemen mutu yang dilakukan oleh SMK di Kota Bandung guna menjaga konsistensi dalam menyiapkan lulusan agar memiliki kemampuan untuk bekerja, melanjutkan pendidikan dan wirausaha?; (a) Bagaimana proses pembejalaran yang dilaksanakan ?; (b) Bagaimana evaluasi hasil pembelajaran yang dilaksanakan?; dan (c) Bagaimana pelaksanaan pengawasan yang dilakukan?; (4) Bagaimanakah penjaminan mutu yang dilaksanakan pada SMK Negeri di Kota Bandung?; dan (5) Bagaimanakah pengembangan model manajemen mutu pendidikan SMK Negeri di Kota Bandung yang dapat direkomendasikan?

Adapun tujuan penelitian ini adalah untuk mengetahui dan memetakan yang berkaitan dengan: (1) Memverifikasi, mendeskripsikan dan memaknai data tentang perencanaan manajemen mutu yang berkaitan dengan pedoman mutu, kebijakan mutu, prosedur operasional baku, dan rumusan standar kompetensi siswa yang ditetapkan oleh pimpinan SMKN di Kota Bandung dalam menyiapkan lulusan yang memiliki kemampuan untuk bekerja, melanjutkan pendidikan dan berwirausaha; (2) Memverifikasi, mendeskripsikan dan memaknai pelaksanaan manajemen mutu yang berkaitan dengan kurikulum dan strategi yang ditetapkan oleh SMK di Kota Bandung; (3) Memverifikasi, mendeskripsikan dan memaknai system pengendalian dan pengawasan yang berkaitan dengan proses pembelajaran, evaluasi hasil pembelajaran, dan pelaksanaan pengawasaan yang dikembangkan oleh SMK di Kota Bandung dalam menyiapkan lulusan yang memiliki kemampuan untuk bekerja, melanjutkan pendidikan dan berwirausaha; (4) Memverifikasi, mendeskripsikan dan memaknai penjaminan mutu yang dilakukan oleh SMK Negeri di Kota Bandung; dan (5) Mendeskripsikan model manajemen mutu pendidikan SMK Negeri di Kota Bandung yang dapat dilaksanakan.

\section{METODE PENELITIAN}

Penelitian ini menggunakan pendekatan kualitatif, karena bertujuan mendeskripsikan dan menganalisis pelaksanaan manajemen mutu SMK Negeri di Kota Bandung, khususnya yang dilaksanakan di SMK Negeri 1 dan 3 dan SMK Pasundan 1. Dalam penelitian ini, peneliti berusaha untuk mengerti, memahami dan mengamati secara mendalam para pengelola sekolah dalam upaya meningkatkan mutu atau relevansi melalui pelaksanaan manajemen mutu, kemudian menafsirkan, memaknai fenomena dan peristiwa yang sesuai dengan masalah yang diteliti.

\section{HASIL DAN PEMBAHASAN}

\section{Perencanaan mutu SMK di Kota Bandung}

Dalammenjalankan proses pendidikandilevel sekolah menengah kejuruan, kepala sekolah melakukan langkah-langkah perencanaan mutu yang berkaitan dengan pengelolaan sekolahnya. Perencanaan mutu di sekolah yang diobservasi lebih menekankan pada komponen kurikulum. Hal ini dilakukan karena dengan kejelasan kurikulum, akan 
menyangkut pada penyedia-an maupun ketersediaan sumber daya yang harus dimiliki oleh sekolah, dalam mendukung PBM yang sesuai dengan kebutuhan belajar peserta didik.

Terkait perencanaan mutu di SMK, khususnya di SMK yang di observasi, pihak sekolah menetapkan berbagai program, antara lain: (a) peningkatan kompetensi guru, melalui kegiatan OJT (on the job trainning), yaitu program magang yang ditujukan pada guru-guru bidang produktif, untuk magang pihak sekolah bekerjasama dengan berbagai perusahaan, misalnya dengan Toserba Yogya, yang berlangsung 3 bulan; (b) program magang bagi calon lulusan, yaitu ditujukan kepada seluruh siswa tingkat III, bagi yang berminat untuk melakukan magang kerja di DU/DI selama menunggu proses penilaian hasil ujian nasional; (c) Program pelatihan oleh DU/DI bagai para siswa, misalnya oleh toserba Yogya; (d) Program peningkatan kualitas dan kuantitas sarana; (d) Menginventarisir dan menyeleksi lembaga atau DU/DI yang akan dijadikan tempat praktek kerja industri. (PRAKERIN) Lembaga tempat prakerin yang benar-benar bisa memberikan pengalaman yang sesuai dengan kompetensi yang telah ditetapkan dalam buku jurnal prakerin; (e) Juga mengundang guru tamu, yaitu dari asosiasi profesi. Misalnya untuk jurusan akutansi dari AAI (Asosiasi AkuntanIndonesia), Administrasi Perkantoran dari ISI (Ikatan Sekretaris Indonesia) dan Asosiasi Perjalanan Wisata Indonesia; (f) Pengembangan buku jurnal Prakerin yang dalam pelaksanaannya mendapatkan masukan dari DU/DI, terutama masukan dalam penetapan kompetensi siswa yang akan dikembangkan selama Prakerin. Prinsip PKL adalah siswa belajar dari lapangan, bukan untuk mengaplikasikan teori yang dipelajari di sekolah di lapangan. Berlangsung selama 3 bulan; (g) Sebelum siswa melakukan prakerin, siswa disiapkan terlebih dahulu, melalui program Beauty
Class. Kegiatan ini berlangsung selama 3 hari. Materi yang diberikan terkait sikap atau tingkah laku dalam bekerja, penampilan, yang meliputi tata cara berrias, berpakaian dan berkomunikasi; (h) Pengembangan matrik kompetensi. Dalam matrik tersebut diidentifikasi kompetensi mana yang bisa dikembangkan di sekolah dan di DU/DI; (i) Program Job Matching atau Job Ekspo; dan (j) Kerja sama dengan DU/DI dalam menetapkan kriteria calon siswa

\section{Pelaksanaan Manajemen Mutu Di SMK Kota Bandung}

Berdasarkan hasil observasi yang telah dilakukan pada SMK yang menjadi objek penelitian, pelaksanaan dalam bagaimana mengelola mutu, pada prinsipnya mengacu kebijakan yang telah ditetapkan oleh pemerintah yang berlandaskan Standar Pengelolaan Minimal dan Undang-undang Sistem Pendidikan Nasional 2003.

Dalam rangka meningkatkan hasil lulusan yang sesuai dengan kebutuhan dunia usaha dan industry, atau lulusannya dapat memiliki kemampuan untuk bekerja, melanjutkan pendidikan dan wirausaha, maka setiap sekolah yang di observasi menerapkan system manajemen mutu yang mengacu pada ISO 9001:2008, yaitu yang berkenaan dengan persyaratan system manajemen mutu (Quality Management System Requirements). Dimana sekolah menerapkan langkahlangkah system manajemen mutu sebagai berikut; (1) Identifikasi proses pelayanan/ bisnis/pendidikan; (2) Menetapkan kebijakan mutu; (3) Menetapkan sasaran mutu dan rencana manajemen mutu; (4) Identifikasi kebutuhan dokumen; (5) Membuat dokumen pedoman dan prosedur mutu; dan (6) Membuat dokumen intruksi kerja

Setelah hal tersebut dilakukan, selanjutnya sekolah melakukan penerapan system manajemen mutu, dengan cara sebagai berikut; (1) Sosialisasi dokumen yang digunakan; (2) Penerapan dokumen sistem 
mutu; (3) Pemantauan penerapan ISO 9001; (4) Melakukan tinjauan manajemen; (5) Mengumpulkan catatan; dan (6) Membuat laporan kinerja penerapan ISO 9001

\section{System Pengendalian dan Pengawasan Manajemen Mutu}

Berkenaan dengan hal tersebut, kepala sekolah bersama-sama dengan wakil kepala sekolah bidang kurikulum melaksanakan supervisi atau pengawasan terhadap seluruh komponen sumber daya yang ada di sekolah, yang bertujuan untuk menjamin agar pelaksanaan kurikulum dan program pembelajaran di SMK dapat berjalan sesuai dengan rencana dan tujuan yang telah ditetapkan.

Berdasarkan hasil wawancara dengan kepala sekolah beserta wakil kepala sekolah, bahwa kegiatan pengawasan yang dilakukan dalam bentuk pengisian lembar monitoring, atau jurnal kegiatan di kelas, serta kepala sekolah atau wakil secara rutin memonitor penampilan mengajar guru melalui monitor CCTV (bagi sekolah yang sudah dilengkapi dengan alat tersebut), atau setiap pagi berkeliling ke setiap kelas untuk melihat kehadiran guru di kelas. Selanjutnya, kepala sekolah atau wakil kepala sekolah menghimpun dan memeriksa administrasi kelas, silabus dan RPP yang dibuat oleh para guru. Sementara ini kegiatan kunjungan kelas, belum secara menyeluruh dilakukan, karena dikhawatirkan dapat mengganggu konsentrasi guru yang sedang mengajar dan siswa yang sedang belajar.

Teknik supervisi yang dilakukan oleh kepala sekolah dan wakil kepala sekolah, menggunakan pendekatan in-formal, yaitu dengan cara menanyakan secara langsung kepada murid mengenai penampilan guru ketika mengajar. Kepala sekolah beranggapan bahwa informasi yang disampaikan oleh siswa adalah sangat penting, karena siswa sebagai pelanggan internal merupakan pihak pertama yang merasakan secara langsung atas kualitas layanan yang diberikan oleh guru sebagai pelaksanakan program pembelajaran di sekolah.

Hasil pengawasan tersebut, oleh kepala sekolah ditindaklanjuti secara rutin, dengan cara mengadakan rapat atau pertemuan dengan seluruh guru dalam rangka melakukan pembinaan, maupun menyampaikan koreksi secara informal terhadap penampilan mengajar guru di kelas, administrasi guru yang meliputi penyusunan Silabus dan RPP. Disamping itu, kepala sekolah mengingatkan dan memberikan motivasi kepada guru untuk selalu melaksanakan tugas dan fungsinya dengan penuh rasa tanggung jawab.

Kegiatan pengawasan dan monitoring bukan saja terhadap pelaksanaan pendidikan yang disekolah saja, tetapi dilakukan juga terhadap kegiatan praktek kerja industri. Kegiatan tersebut dilakukan oleh guru, yang ditugaskan sebagai pembimbing. Daklam pelaksanannya, kegiatan monitoring tersebut dilakukan minimal sebanyak tiga kali, atau disesuaikan dengan kebutuhan lapangan.

Implementasi monitoring yang dilalukan oleh guru, dilakukan dengan membawa lembar monitoring. Dimana setiap kegiatan monitoring, guru harus menggali dan mendapatkan informasi mengenai kegiatan yang dilakukan siswa, kemampuan dalam melaksanakan tugas pekerjaannya, perilaku dan masalah-masalah yang dihadapi siswa selama praktek kerja di industri. Disamping itu, guru harus berupaya untuk mendapatkan masukan dari dunia usaha/industri, baik yang menyangkut kemampuan dan kinerja siswa, maupun program prakerin yang disusun sekolah. Saran dan dari dunia usaha/industri dijadikan sebagai umpan balik bagi pihak sekolah untuk perbaikan atau penyempurnaan kurikulum, rumusan kompetensi maupun untuk penyempurnaan pengelolaan program prakerin itu sendiri. Dengan demikian pihak sekolah melakukan upaya perbaikan atau penyempurnaan secara 


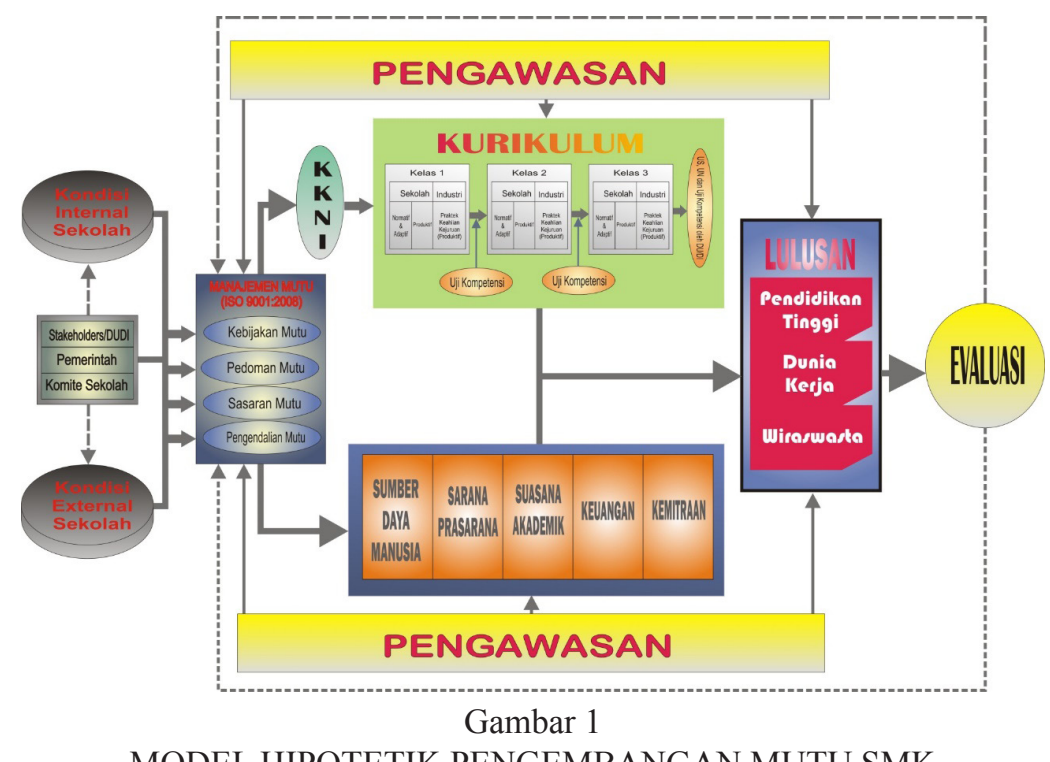

terus-menerus (continuous improvement). Upaya perbaikan ini dilakukan oleh kepala sekolah melalui pertemuan dengan para guru, atau mengadakan pertemuan dengan dunia usaha/industri, juga memberikan kesempatan kepada setiap program keahlian untuk melakukan perbaikan sesuai dengan masukan yang disampaikan oleh dunia usaha/ industri.

\section{Penjaminan Mutu pada SMK di Kota Bandung}

Penjaminan mutu pendidikan di lingkungan SMK, ditujukan untuk memelihara dan meningkatkan mutu hasil pendidikannya secara berkelanjutan, yang dijalankan oleh suatu lembaga pendidikan secara internal untuk mewujudkan visi dan misinya, serta untuk memenuhi kebutuhan stakeholders melalui penyelenggaraan wawasan wyata mandala. Pencapaian tujuan penjaminan mutu melalui kegiatan penjaminan mutu yang dijalankan secara internal oleh sekolah, akan dikontrol dan diaudit melalui kegiatan akreditasi yang dijalankan oleh BAN-PT atau lembaga lain secara eksternal. Dengan demikian, obyektivitas penilaian terhadap pemeliharaan dan peningkatan mutu pendidikan sekolah menengah kejuruan secara berkelanjutan dapat diwujudkan.

Penjaminan mutu pendidikan di SMK, diselenggarakan melalui berbagai model manajemen kendali mutu. Salah satu model manajemen yang diterapkan dan digunakan adalah model PDCA (Plan, Do, Check, Action) yang akan menghasilkan pengembangan berkelanjutan (continuous improvement) atau kaizen mutu pendidikan sekolah menengah kejuruan.

\section{Model hipotetik}

Berdasarkan model hipotetik yang telah digambarkan tersebut, berikut ini di jelaskan alur kerja model hipotetik pengembangan mutu SMK di Kota Bandung yang dapat direkomendasikan, yatu sebagai berikut.

Sekolah menengah kejuruan merupakan jenjang sekolah formal yang memiliki ciri khas tersendiri bahkan ada sebuah filosofi yang memandang pendidikan kejuruan sebagai pihak yang harus bertanggung jawab atas persiapan orang untuk bekerja, dengan adanya filisofi ini maka akan mempunyai dampak, yakni harus tersedia secara bervariasi jenis pendidikan yang berfungsi untuk menyiapkan orang untuk bekerja.

Sekolah menengah kejuruan sebagai lembaga pendidikan yang berfungsi untuk menyiapkan siswa untuk bekerja atau wirausaha dan mengikuti pendidikan lebih lanjut, hendaknya mampu memberikan layanan pendidikan yang bermutu, yakni yang dapat memenuhi 
harapan dan kebutuhan pelanggan eksternal, yaitu dunia usaha/industri maupun internal yaitu siswa. Layanan yang bermutu yang diberikan oleh pihak sekolah dapat dilihat dari aspek pendidikan sebagai suatu sisten, yaitu 1). Input, yang meliputi: visi, misi, tujuan sekolah, kebijakan, kurikulum atau program pembelajaran, fasilitas belajar, rumusan standar kompetensi, tenaga kependidikan yang profesional. 2). Proses atau strategi pembelajaran yang dikembangkan oleh pihak sekolah atau guru, yang meliputi penggunaan strategi pembelajaran dan evaluasi serta partisitipasi dunia usaha dalam perencanaan, pelaksanaan PBM dan evaluasi pembelajaran,3) sistem pengawasan dan pengendalian, yang mencakup penetapan ruang lingkup pengawasan, strategi pengawasan, tindak lanjut pengawasan berupa upaya peningkatan dan perbaikan pada rumusan kompetensi siswa, kurikulum, pelaksanaan proses pembelajaran dan sistem evaluasi pembelajaran sehingga relevan dengan kebutuhan dunia kerja maupun masyarakat.

Perencanaan mutu meliputi Pedoman mutu, Kebijakan mutu dan Rumusan standar kompetensi siswa. Keterlibatan DU/DI dalam proses pendidikan, memungkinkan para siswa memiliki pengalaman belajar yang lebih konkrit, sehingga akan menjadi bekal yang sangat berharga dalam bekerja, berwirausaha maupun melanjutkan pendidikan.

Pengembangan model manajemen mutu di sekolah SMK menggunakan pendekatan evaluasi CIPP yaitu contex, input, proses dan product hal ini dipilih karena model ini dianggap sebagai sebuah model yang menekankan bukan pada membuktikan melainkan meningkatkan sebuah perkembangan dan peningkatan.

Evaluasi konteks mencakup analisis masalah yang berkaitan dengan lingkungan program atau kondisi obyektifyang akan dilaksanakan, dalam hal ini model pengembangan mutu menganalisis kondisi internal dan eksternal sekolah yaitu melihat kondisi dari stakeholder/ DUDI, komite sekolah dan pemerintah dengan tujuan untuk membuat sebuah perencanaan mutu yang akan diterapkan. Stakeholder/ DUDI akan memberikan pengaruh terhadap penerapan mutu di sekolah SMK karena stakeholder merupakan orang yang akan menerima lulusan dari SMK sehingga standar lulusan dari stakeholder menjadi pertimbangan dalam perencanaan mutu. Komite sekolah berperan penting dalam penyusunan mutu disekolah karena komite sekolah merupakan perwakilan masyarakat yang akan menjawab hasil akhir dari lulusan SMK yang dibutuhkan oleh masyarakat. Pemerintah juga mengambil bagian dalam perencanaan mutu untuk mengidentifikasikan kebutuhan-kebutuhan apa saja yang belum terpenuhi dalam penerapan mutu sekolah. Untuk mendapatkan mutu lulusan yang berkualitas, mutu pendidikan dan lulusan harus di perbaiki. Perbaikan mutu lulusan hanya dapat terjadi jika di dahului perbaikan mutu pendidikan di lingkungan sekolah yang melibatkan stakeholder/DUDI, komite sekolah dan pemerintah.

Mutu sekolah merupakan pencapaian tujuan pendidikan dan kompentensi lulusan yang telah ditetapkan oleh sekolah di dalam rencana strategisnya atau telah sesuainya antara tujuan pendidikan yang dilaksanakan dengan standar akademik yang telah ditentukannya. Hal ini berangkat dari konsep penjaminan mutu, bahwa sekolah dinyatakan bermutu apabila tersebut memiliki kemampuan untuk menetapkan dan mewujudkan visi melalui misi dan kemampuan memenuhi kebutuhan stakeholders yang meliputi kebutuhan masyarakat (society needs), dunia kerja (industrial needs) dan profesi (professional needs). Visi, misi harapan dan tujuan dari dituangkan dalam pedoman mutu sekolah, kebijakan mutu, sasaran muu, dan pengendalian mutu. Pedoman mutu sekolah merupakan sebuah acuan dalam 
menjalankan proses pendidikan di sekolah. Pedoman mutu merupakan panduan bagi setiap sekolah dalam mengimplementasikan dan mencapai mutu yang diharapkannya. Secara garis besar, pedoman mutu tersebut mencakup istilah dan definisi yang digunakan sekolah, peraturan, undang-undang, standar akreditasi, program setifikasi dan pelayanan pendukung, atau dapat dikatan sebagai suatu sistem manajemen mutu.

Kebijakan mutu merupakan wujud komitmen mutu yang dituangkan dalam pernyataan formal yang menunjukkan tekad untuk selalu memberikan yang terbaik kepada pelanggan/ pemangku kepentingan. Penyusunan kebijakan mutu tersebut, mengacu pada Visi, Misi pendidikan yang ditetapkan oleh Sekolah dan Tujuan pendidikan secara nasional bagi setiap sekolah. Sekolah perlu memastikan kebijakan mutu dipahami oleh seluruh personil dan menjadi acuan dalam penetapan target, penyusunan perencanaan dan evaluasi.Dalam upaya merealisasikan kebijakan mutu, kepala sekolah meminta kepada semua pihak, seperti: ketua program studi/keahlian, wakil kepala sekolah, guru, petugas BP, pengelola BKK (Bursa Kerja Khusus) untuk menyusun program dan sasaran mutu yang akan dicapai. Pencapaian sasaran mutu ini yang akanmenjadi indikator keberhasilan dari kebijakan yang sudah ditetapkan. Untuk mencapai sasaran mutu yang tertuang dalam pedoman mutu maka diperlukan pengendaian mutu oleh semua stakholder sekolah.

Pedoman mutu, kebijakan, sasaran dan pengendalian mutu ini akan menetapkan beberapa staregi dalam meningkatkan kualitas sumber daya manusia, meningkatkan efektivitas dan efisiensi kinerja sekolah, meningkatkan sarana dan prasarana pendidikan. Dan meningkatkan kesejahteraan. Beberapa kebijakan yang ditetapkan oleh kepala sekolah, ditujukan pada aspek kurikulum, organisasi dan manajemen, ketenagaan, sarana prasarana, pembiayaan, kesiswaan, hubungan industri serta lingkungan/ budaya sekolah.

Kebijakan dalam bidang kurikulum, berkaitan dengan pengembangan kurikulum yang sesuai kebutuhan, penyusunan rencana/ program pembelajaran yang mengacu pada pedoman SMK standar nasional, penerapan multi metoda dan media dalam pembelajaran, mendorong kreativitas dan inovasi dalam proses pembelajaran, pengembangan system evaluasi. Standar kompetensi yang ditetapkan di SMK tidak hanya mengacu kepada SKKNI dan tuntutan satu industri atau perusahaan, melainkan mempertimbangkan masukan dari sejumlah dunia usaha/industri dalam bidang keahlian sejenis dengan berbagai karakteristik dan kondisi yang sangat beragam. Untuk itu, khususnya dalam menetapkan standar kompetensi untuk bidang produktif pihak sekolah biasanya mengundang berbagai dunia usaha/industri, juga organisasi profesi, seperti: IAI (Ikatan Akutansi Indonesia) ISI (Ikatan Sekretaris Indonesia) ASITA (Asociation of Indonesian Tour and Travel Agency), serta unsur perguruan tinggi yang memiliki program studi atau jurusan yang relevan dengan program keahlian yang ada di SMK. Dengan melalui pendekatan ini dimungkinkan rumusan kompetensi yang ditetapkan dapat menggambarkan atau secara umum mewakili berbagai tuntutan utama dari dunia usaha/industri yang kemudian menjadi standar kompetensi tamatan SMK.

Kebijakan dalam bidang ketenagaan, berkaitan dengan upaya peningkatan profesionalisme guru, baik yang berkaitan dengan keahliannya maupun dalam penguasaan bahasa asing. Kebijakan mutu harus didukung oleh guru-guru yang memiliki kemampuan yang handal, memiliki komitmen, dan dedikasi kerja yang tinggi, dengan didukung oleh sumber daya manusia yang handal diharapkan efektivitas program pembelajar bisa terwujud. Dukungan sarana dan prasarana yang baik, yang disertai dengan tata kelola yang tertib memungkinkan 
program sekolah bisa berjalan dengan baik, serta dengan dukungan dunia usaha/industri yang tinggi, diharapkan program pendidikan yang menggunakan system ganda dapat berjalan efektif, yang pada akhirnya diharapkan siswa yang tamat menyelesaikan program studinya dapat memiliki kompetensi yang bisa memenuhi harapan dunia usaha/ industri, yang pada gilirannya permintaan tenaga terampil pada SMK bisa lebih meningkat. Kebijakan dalam bidang sarana dan prasarana pendidikan, berkaitan dengan upaya pemenuhan kebutuhan fasilitas pendidikan serta optimalisasi pemenfaatan sarana yang ada. Kebijakan dalam bidang pembiayaan, adanya alokasi dana untuk berbagai kegiatan pengembangan personil, pengembangan kurikulum, program kesiswaan, riset penelusuran tamatan. Sedangkan kebijakan yang berkaitan dengan hubungan industri diarahkan pada upaya peningkatan kerjasama sekolah dengan dunia usaha/industri, upaya meningkatkan pemasaran lulusan. Kebijakan dalam bidang organisasi dan manajemen diarahkan pada pengembangan struktur organisasi yang disertai dengan mekanisme kerja dan deskripsi tugas serta pengembanganm SIM dan internet. Sedangkan kebijakan dalam bidang kesiswaan diarahkan pada peningkatan kualitas uji kompetensi, pembinaan siswa melalui kegiatan ekstrakurikuler dan bimbingan belajar sebagai upaya peningkatan kualitas hasil belajar/NEM, pemgembangan sistem penerimaan siswa baru yang bisa menjaring siswa yang memiliki potensi dan minat untuk mengikuti pendidikan di SMK.

Keseluruhan proses pencapaian mutu haruslah diawasi sehingga tidak ada penyimpangan yang terjadi dalam pencapaian sasaran mutunya. Sasaran mutu yang utama adalah untuk mempersiapkan lulusan untuk melanjutkan sekolah ke pendidikan tinggi, memasuki dunia kerja maupun berwiraswasta. tahap akhir dari sebuah penjaminan mutu adalah evaluasi dari semua kegiatan yang dilakukan sehingga menimbulkan feedback dan perbaikan dalam meningkatkan mutu selanjutnya.

Evaluasi dilakukan oleh sekolah secara menyeluruh ditujukan untuk memelihara dan menemukan faktor-faktor yang memungkinkan untuk dapat lebih meningkatkan mutu hasil pendidikannya secara berkelanjutan. Evaluasi dimaksudkan untuk menetapkan dan menerapkan proses perbaikan berkelanjutan dari system manajemen mutu yang telah dilakukan, sehingga akan memberikan masukan atau timbal balik dalam penetapan sasaran mutu, pedoman mutu, kebijakan mutu dan pengendalian mutu serta proses mutu yang sedang berlangsung. Hal tersebut perlu dilakukan karena akan mempengaruhi terhadap kurikulum pembelajaran serta peningkatan kualitas sumber daya baik sumber daya baik guru, fasilitas dan keuangan untuk dapat menciptakan kondisi lingkungan dan suasana akademik yang kondusif, sehingga lulusan SMK menjadi lulusan yang siap bersaing baik dalam melanjutkan sekolah maupun dalam memasuki dunia kerja ataupun membuat usahanya sendiri. Dengan demikian tahap akhir dari sebuah penjaminan mutu adalah evaluasi dari semua kegiatan yang dilakukan sehingga menimbulkan feedback dan perbaikan dalam meningkatkan mutu selanjutnya.

\section{KESIMPULAN}

Model manajemen mutu yang saat ini dilakukan oleh sekolah yang diteliti, pada prinsipnya telah dilaksanakan sesuai dengan aturan dan pedoman yang berlaku dalam meningkatkan mutu pendidikannya. Namun, masih ada kendala dalam hal menyesuaikan hasil lulusannya dengan pihak-pihak terkait seperti dengan dunia usaha dan industry, dimana lulusannya setelah lulus ternyata masih memerlukan tambahan keilmuan atau pengalaman yang sesuai dengan kebutuhan dunia usaha dan industry. 
Hal ini terjadi karena, pada saat PKL, terdapat beberapa siswa yang tidak sesuai dengan bidang yang seharusnya menjadi focus pengembangan keterampilan sesuai dengan jurusan yang telah dipilihnya. Disamping itu, kebijakan mutu dan strategi implementasi dalam menerapkan penjaminan mutu baru dipandang sebagai slogan atau hanya untuk memenuhi kebutuhan akreditasi saja, belum sepenuhnya sekolah yang bersangkutan mengacu kepada kebijakan mutu yang telah ditetapkan dalam menjalankan operasional pendidikan yang dapat meningkatkan mutu pendidikan.

\section{DAFTAR PUSTAKA}

Ariani, Dorothea Wahyu. 2003..Manajemen Kualitas, Pendekatan sisi Kualitatif, Ghalia Indonesia, Jakarta

Anonim, (2005), Evaluasi Program Studi Berbasis Evaluasi Diri (EPSBED), Direktorat Jenderal Pendidikan Tinggi, Departemen Pendidikan Nasional.

Dedi Supriadi (Editor) (2002). Sejarah Pendidikan Teknik dan Kejuruan di Indonesia: Membangun Manusia Produktif, Dirjen Dikdasmen, Diknas

Direktorat Jenderal Pendidikan Tinggi, (2003), Pedoman Penjaminan Mutu Perguruan Tinggi, Jakarta : Depatemen Pendidikan Nasional

Direktorat Jenderal Pendidikan Tinggi, (2004),Praktek Baik Dalam Penjaminan Mutu Pendidikan Tinggi, Buku I Proses Pembelajaran, Departemen Pendidikan Nasional.

Evans and Lindsay, (2005), The Management and Control of Quality (International Student Edition), South-Western, Printed in Singapore.

Goetsch, DL, and Davis, SB, (2006), Quality Management : Introduction to Total Quality Management for Production, Processing, and Services, 5th ed., New Jersey : Pearson International Inc.

Goodlad, S.(1995), The Quest for Quality, SRHE and Open University Press, Buckingham

Herman, J.L, \& Herman, J.J, (1995). Total Quality Management (TQM) For Education, Journal of Education Technology. May-
June (halaman 14-18).

Hedwig, Rinda. Gerardus Polla (2006). Model Sistem Penjaminan Mutu, Graha Ilmu, Jakarta

Indra Jati Sidi (2001), Membangun Masyarakat Belajar, Diknas Jakarta

IPCC (2006). Quality Assurance and Quality Control, Tersedia: www.ipcc-nggip.iges.or.jp.

Kantor Jaminan Mutu (2002), Buku Panduan Jaminan Mutu Pendidikan Tinggi Universitas Gadjah Mada, Universitas Gadjah Mada, Edisi Pertama.

Lewis and Smith. 1996. Total Quality in Higher Education. Delray Beach. Florida. St. Lucie Press.

Liston, C. (1999). Managing Quality Standards, Open University Press, Buckingham, Philadelphia.

Rauner, Felix. (2007), Practical Knowledge and Accupational Competence, European Journal of Vocational Training No. 40 2007/1.

Riley, K.A., and Nuttall, D.L. (ed), (1994), Measuring Quality: Education Indicators, London : The Falmer Press

SEDL., (1994), Total Quality: A Missing Piece for Educational Improvement ?, SEDL Issues About Leadership An Imperatif for Successful Change.htm.

Syafaruddin, (2002), Manajemen Mutu Terpadu dalam Pendidikan ; Konsep, Strategi dan Aplikasi, Jakarta : Grasindo.

Slamet Margono. 1995. Manajemen Perguruan Tinggi pada Era Global: Suatu Gagasan Menuju Efisiensi. Unmer Malang Grasindo Jakarta

1996. Filsafat dan Prinsip-Prinsip Manajemen Mutu Terpadu di Perguruan Tinggi, Jakarta: Heds Project

Sallis, Edward. (2006), Total Quality Management in Education, terj. Ahmad Ali Riyadi. IRCiSod, Yogyakarta

Sanusi, A., (1990). Pendidikan Alternatif; Menyentuh Aras Dasar Persoalan Pendidikan dan Kemasyarakatan, Bandung: PPs IKIP Bandung.

Sasmoko, Evaluasi Proses Pembelajaran Sebagai Kontrol Kualitas di Lembaga Pendidikan yang Otonom, Portal Informasi Indonesia, http:/www.depdiknas.go.id /jurnal/31/ evaluasi proses pembelajaran seb.htm. 